\title{
Assessment of glacial-earthquake source parameters
}

\author{
STEPHEN A. VEITCH, MEREDITH NETTLES \\ Lamont-Doherty Earth Observatory of Columbia University, Palisades, NY, USA \\ Correspondence: Stephen A. Veitch <veitch@/deo.columbia.edu>
}

\begin{abstract}
Glacial earthquakes are slow earthquakes of magnitude $M \sim 5$ associated with major calving events at near-grounded marine-terminating glaciers. These globally detectable earthquakes provide information on the grounding state of outlet glaciers and the timing of large calving events. Seismic source modeling of glacial earthquakes provides information on the size and orientation of forces associated with calving events. We compare force orientations estimated using a centroid-single-force technique with the calving-front orientations of the source glaciers at or near the time of earthquake occurrence. We consider earthquakes recorded at four glaciers in Greenland - Kangerdlugssuaq Glacier, Helheim Glacier, Kong Oscar Glacier, and Jakobshavn Isbræ - between 1999 and 2010 . We find that the estimated earthquake force orientations accurately represent the orientation of the calving front at the time of the earthquake, and that seismogenic calving events are produced by a preferred section of the calving front, which may change with time. We also find that estimated earthquake locations vary in a manner consistent with changes in calving-front position, though with large scatter. We conclude that changes in glacial-earthquake source parameters reflect true changes in the geometry of the source glaciers, providing a means for identifying changes in glacier geometry and dynamics that complements traditional remote-sensing techniques.
\end{abstract}

KEYWORDS: calving, cryoseismology, glacier geophysics, ice/ocean interactions, remote sensing, seismology

\section{INTRODUCTION}

Glacial earthquakes are earthquakes of magnitude $M \sim 5$ associated with major marine-terminating glaciers in Greenland (e.g. Ekström and others, 2003) and Antarctica (Nettles and Ekström, 2010; Chen and others, 2011). Glacial earthquakes occur at glaciers with near-grounded calving fronts (Veitch and Nettles, 2012) when icebergs detach from the glacier calving front and capsize (Amundson and others, 2008; Nettles and others, 2008; Tsai and others, 2008; Veitch and Nettles, 2012; Murray and others, 2015a). Since first detected, glacial earthquakes have shown promise as a tool for monitoring large outlet glaciers, and focused, multidisciplinary studies have resulted in a rapid refinement of our understanding of the source mechanism of glacial earthquakes. During calving, iceberg acceleration (Nettles and others, 2008; Tsai and others, 2008; Nettles and Ekström, 2010; Veitch and Nettles, 2012) and related hydrodynamic pressure changes (Murray and others, 2015a) exert a seismogenic force on the solid earth. The seismic surface waves generated by these forces are globally observable, and may be used to determine source parameters describing the glacial earthquake (Ekström and others, 2003; Nettles and Ekström, 2010). Waveform analysis using a centroid-single-force (CSF) model (Kawakatsu, 1989) has been applied systematically to events in Greenland, where most glacial earthquakes occur, and catalogs of source parameters for these events have been published for the years 1993-2010 (Tsai and Ekström, 2007; Veitch and Nettles, 2012).

The CSF source modeling performed by Tsai and Ekström (2007) and Veitch and Nettles (2012) uses intermediateperiod surface waves (35-150 s) and an assumed sourcetime function to obtain earthquake source parameters. These parameters consist of a centroid time and location as well as a three-dimensional force vector. The centroid location represents the spatial centroid of the finite area on the earth's surface over which the force acts. The azimuth of the force vector is expected to be oriented opposite to the direction of iceberg acceleration, perpendicular to the glacier calving front (Nettles and Ekström, 2010; Veitch and Nettles, 2012). Veitch and Nettles (2012) linked earthquake characteristics to glacier dynamics, including the grounding state and seasonal and interannual retreat and advance of the calving front, and assessed location accuracy for earthquake centroids, finding a mean location error of $\sim 15 \mathrm{~km}$.

Veitch and Nettles (2012) confirmed qualitatively that most glacial earthquakes have force directions approximately perpendicular to the calving front, but were not able to provide a more detailed assessment of the accuracy of the force orientations. Such an assessment is required to evaluate the reliability of changes in earthquake source parameters as an indicator of changes in glacier dynamics, and to allow identification of anomalous glacial earthquakes. For example, at Helheim Glacier Veitch and Nettles (2012) noted temporal variability in force orientations, with a generally clock-wise trend since 2000 (Fig. 1), but seismic data constraints have changed over time, and the estimates were obtained by two separate sets of authors (1993-2005: Tsai and Ekström, 2007; 2006-10: Veitch and Nettles, 2012). At Kong Oscar Glacier, Veitch and Nettles (2012) noted a number of apparently anomalous glacial earthquakes for which the estimated force orientations were nearly parallel to the calving front, perpendicular to the expected force orientation, for which there is no obvious explanation.

An ideal means of evaluating the uncertainty in estimated force azimuth would be to measure the calving fronts of source glaciers immediately before and after a number of 




Fig. 1. Glacial-earthquake force orientations estimated by teleseismic waveform inversion for events at Helheim Glacier 1999-2010 (Tsai and Ekström, 2007; Veitch and Nettles, 2012). Dashed line shows mean force orientation for this time period.

glacial earthquakes and then compare them with force orientations estimated from seismic data. This approach is rarely possible due to limitations imposed by the availability of satellite or other imagery, and because of the need to identify the section of the calving front that generated the earthquake. A previous study (Walter and others, 2012) was able to identify precisely the source region of a glacial earthquake that occurred at Jakobshavn Isbræ on 21 August 2009. The source region, the measured calving-front orientation, and the force orientation for that event estimated by Veitch and Nettles (2012) are shown in Figure 2. This glacial earthquake has been discussed in detail in at least three additional prior studies (Walter and others, 2012; Podrasky and others, 2014; Sergeant and others, 2016) and is the best individually

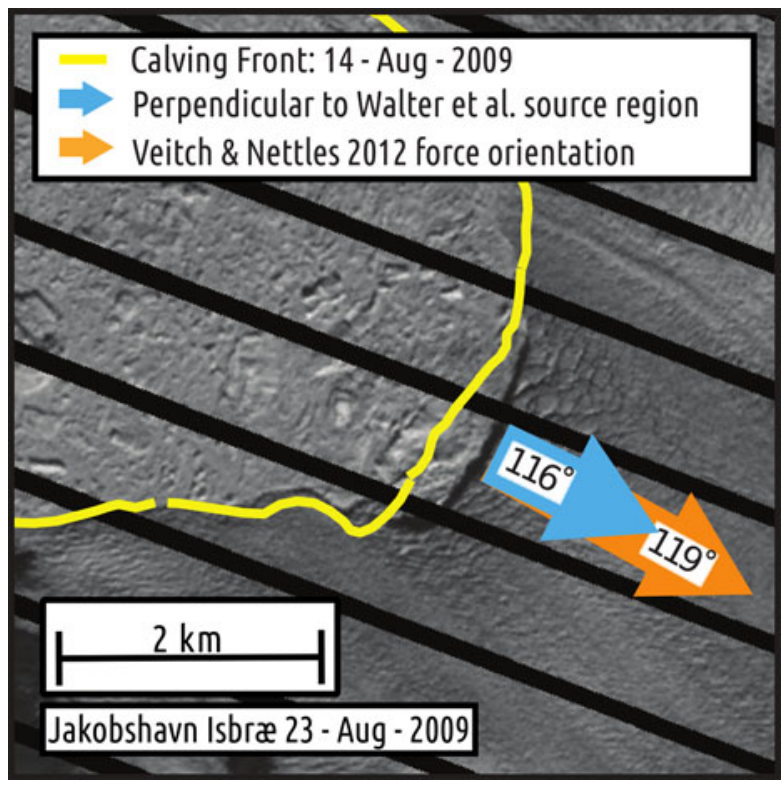

Fig. 2. Comparison of earthquake source parameters and calvingfront geometry for a glacial earthquake occurring on 21 August, 2009. The source region was identified by Walter and others (2012). Landsat 7 image shows the calving front of Jakobshavn Isbræ on 23 August, 2009, after a seismogenic calving event, with the geometry of the calving front prior to the earthquake indicated in yellow. The angle perpendicular to the post-earthquake calving front is shown by the blue arrow. The earthquake force orientation determined by Veitch and Nettles (2012) is shown in orange. This image shows only the southern calving margin of Jakobshavn Isbræ. studied glacial earthquake of which we are aware. The orientation of the calving front in the source region very closely matches the force orientation of the event estimated by Veitch and Nettles (2012), a promising result. The average force orientation of the largest sub-event of Sergeant and others (2016) differs by only $3^{\circ}$ from the force azimuth of Veitch and Nettles (2012). The force orientation of Walter and others (2012) differs by a larger amount $\left(30^{\circ}\right)$, likely owing to that study's use of a narrower, higher frequency band (Sergeant and others, 2016).

Here, to assess the accuracy of a larger group of published force-orientation estimates, we compare the range of calvingfront orientations observed at several glaciers over time with force-orientation estimates for the same time period. We select four glaciers for analysis: Kangerdlugssuaq Glacier, Helheim Glacier, Kong Oscar Glacier, and Jakobshavn Isbræ. These glaciers are active producers of glacial earthquakes, accounting for $59 \%$ of the events in the published catalogs of Tsai and Ekström (2007) and Veitch and Nettles (2012). Veitch and Nettles (2012) noted that earthquake locations at one glacier, Helheim Glacier in East Greenland, appeared to change over time in a manner related to changes in the position of the calving front, but did not explore the observation further. Because our analysis of calving-front orientations also generates estimates of calving-front position, we compare calving-front positions and earthquake locations at the selected four glaciers as well.

\section{DATA AND METHODS}

\subsection{Earthquake source parameters}

We use glacial-earthquake locations and force orientations from 179 glacial earthquakes occurring in 1999-2010 as the basis of our analysis. We obtain these parameters from the previously published solutions of Tsai and Ekström (2007) and Veitch and Nettles (2012). Both studies use intermediate-period surface waves obtained from globally distributed seismic stations and invert for CSF source parameters (Kawakatsu, 1989; Ekström and others, 2003) using a methodology similar to that routinely employed for tectonic earthquakes of similar magnitudes (Ekström and others, 2012).

Glacial-earthquake force orientations are reported in the source publications with azimuths ranging from $-180^{\circ}$ to $+180^{\circ}$ east of north. However, several studies (Tsai and Ekström, 2007; Veitch and Nettles, 2012; Walter and others, 2012) have identified a $180^{\circ}$ ambiguity in the force orientations. We therefore simplify the published results and express all angles as positive, ranging from $0^{\circ}$ to $+180^{\circ}$. That is, a glacial earthquake with a reported force azimuth of $-45^{\circ}$ is considered in this study to have an azimuth of $135^{\circ}$.

The glacial-earthquake locations we use have a mean error of $15 \mathrm{~km}$ (Veitch and Nettles, 2012), which is large in comparison with the glacier dimensions. We consider average glacial-earthquake locations computed over multiple years in our analysis. We first determine mean earthquake locations at each glacier for each year of our study period and then calculate a multi-year mean location. We weight the annual means by the number of glacial earthquakes occurring in each year. We compute the multi-year mean locations for four non-overlapping time periods consisting of the years 1999-2001, 2002-04, 2005-07, and 2008-10. 
The locations show systematic offsets from the expected true locations at the calving front, likely because of inaccuracies in the earth model used for the seismic inversion (Smith and Ekström, 1997; Veitch and Nettles, 2012). This effect is visible in Figure 3 for Helheim Glacier, where event locations are systematically biased to the northwest. Here, we are interested only in variations in glacial-earthquake source location in the direction of glacier retreat or advance. We determine the geographic center line of each glacier from satellite imagery and project the mean locations onto this line. We then describe the projected positions as relative positions along the center line. We define the origin $(0 \mathrm{~km})$ as the multi-year mean location for 1999 2001, with inland motion (the direction of glacier retreat) defined as positive and seaward motion (the direction of glacier advance) defined as negative.

The steps in this processing are shown graphically in Figure 3 for Helheim Glacier. The upper panel shows the



Fig. 3. (Top) Glacial-earthquake locations, force orientations and calving-front positions for Helheim Glacier 1999-2010, colour coded by year. (Bottom) Mean earthquake locations and calvingfront positions for the four 3-year periods discussed in this study (1999-2001, 2002-04, 2005-07, and 2008-10). The dashed line represents the glacier center line, and arrows show the projections of the mean earthquake locations onto that line. (Inset) Location of map area shown in the top and bottom panels in Greenland (Helheim Glacier $(\mathrm{H})$ ), as well as the locations of the other glaciers discussed in this study: Kong Oscar Glacier (KO), Kangerdlugssuaq Glacier (K) and Jakobshavn Isbræ (J). Background is a Landsat 7 image from 4 August 2005. source location of each glacial earthquake, colour-coded by year of occurrence. The lower panel shows the weighted mean locations, the center line of the glacier (dashed orange line), and the projections of the multi-year mean locations onto the centerline.

\subsection{Calving-front orientation}

We measure the glacier calving fronts from Landsat 7 imagery, which is available starting in 1999 and remains available for the duration of our study period. We use the pan-chromatic band, which has a ground resolution of $15 \mathrm{~m}$. We selected Landsat 7 imagery because of its high resolution, good temporal coverage, and ease of access. While other satellites, notably MODIS, provide imagery with higher temporal resolution, and with spatial resolution sufficient to determine calving-front position accurately, the higher spatial resolution offered by Landsat 7 is required to obtain measurements of sufficient precision for accurate determination of calving-front orientation. The temporal resolution offered by Landsat 7 is sufficient for our primary purpose of assessing variability in calving-front orientation. Imagery obtained by Landsat 7 after 31 May 2003 contains unimaged sections due to the failure of the instrument's scan-line-corrector (SLC). The presence of unimaged sections affects our ability to obtain measurements in some cases. Landsat data are unavailable during the winter, creating data gaps during winter months.

For each glacier, we select the time period for which we estimate the calving-front geometry based on a combination of image availability and the timing of glacial-earthquake occurrence. The latest date for which published glacial-earthquake source parameters are available is 2010. For Helheim Glacier and Kangerdlugssuaq Glacier, we consider all available imagery from 1999-2010. At Kong Oscar Glacier, the onset of glacial-earthquake production occurred in 2002 (Tsai and Ekström, 2007), following the retreat of the terminus to a location near the grounding line (Veitch and Nettles, 2012). At Kong Oscar Glacier, we therefore consider imagery from 2002-10. Earthquake occurrence at Jakobshavn Isbræ has been sporadic, with earthquakes occurring in 1998 and 1999 when the terminus was at a pinning point, no glacial earthquakes during 2000-04 when the tongue was floating, and steady production beginning in 2005 (Veitch and Nettles, 2012). At Jakobshavn Isbræ we restrict our analysis to 1999 and later years in which glacial earthquakes were recorded, and we analyze imagery only from months during which glacial earthquakes occurred, along with the preceding and following months.

We begin by selecting Landsat 7 scenes that completely contain the calving front and are relatively free of cloud cover. Several example images are shown in Figures 4 and 5. We manually digitize the calving front on each image, selecting as many points as necessary to capture the shape and position of the front, leaving not more than $100 \mathrm{~m}$ between points. We exclude portions of the calving front that are obscured by SLC errors, rather than interpolating across them, and we exclude sections of the calving front within $500 \mathrm{~m}$ of the fjord walls. An example of a digitized calving front is shown in Figure $4 \mathrm{~b}$. Figure 5 shows all of the calving fronts digitized for this study.

We choose to exclude the marginal sections of the calving front (within $500 \mathrm{~m}$ of the fjord walls) because we believe that slow, thin ice is unlikely to play an important role in glacial-earthquake seismogenesis. Additionally, these 

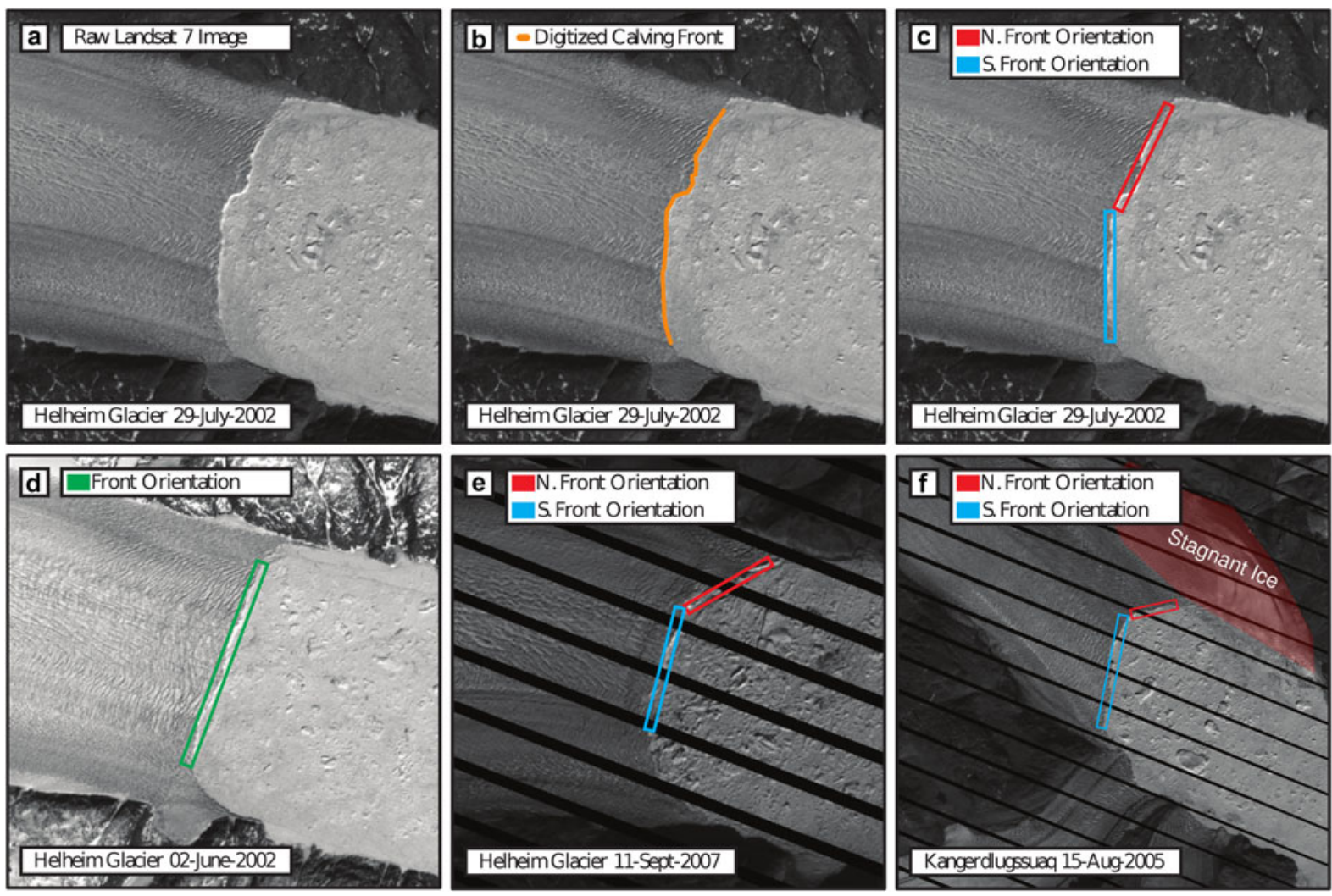

Fig. 4. The process for digitizing a calving front and calculating its orientation are shown in (a-c); additional examples are shown in (d-f). (a) The base image prior to processing. (b) The digitized calving front. (c) Two sections of the calving front for which we calculated orientation separately. (d) A calving front well described by a single angle. (e) In this image, the southernmost sections of the calving front lack a clear transition from glacier to ice mélange and have been excluded from the analysis. SLC errors are present in this image. (f) An example from Kangerdlugssuaq Glacier showing the exclusion of slow ice from the embayment to the north of the glacier (shaded in light red). The scale of images (a-e) is consistent; the highlighted (blue and red) portion of the calving front in (c) is $\sim 5.5 \mathrm{~km}$. The highlighted (blue and red) segment in (f) is $\sim 5.0 \mathrm{~km}$.

portions of the calving front often lack a clearly identifiable transition from glacier ice to ice mélange, making it difficult to digitize the calving front accurately. However, in the case of Kong Oscar Glacier, we include sections of the glacier closer to the southeastern edge of the calving front than $500 \mathrm{~m}$. The far-southeast portion of the Kong Oscar calving front does not appear to be stagnant, is one of the most variable sections of the calving front, and may be accurately digitized.

SLC errors are of particular concern in imagery of Kong Oscar Glacier and the northern ice stream of Jakobshavn Isbræ. In these locations, SLC errors are nearly parallel to the calving fronts in images where they occur, and may obscure considerable portions of the calving front. In some such cases, the position of the calving front can be determined to within the width of the error, but it is not possible to assess the orientation of the calving front accurately, and we exclude these images from our analysis. In imagery of Helheim Glacier, Kangerdlugssuaq Glacier, and the southern ice stream of Jakobshavn Isbræ, SLC errors are nearly perpendicular to the calving front (as seen in Figs 4e, f). Thus, while images at these glaciers may have multiple SLC errors impinging on the calving fronts, their effect on our ability to estimate the calving-front orientation is small.

To estimate the orientation of each digitized calving front, we first interpolate the digitized calving front so that it is represented as a series of $X, Y$ coordinates with $1 \mathrm{~m}$ separation, excluding sections affected by SLC errors. We then fit one or two straight line segments to the interpolated calving front using an orthogonal linear regression, as shown in Figures $4 c-f$. We report the orientation of the calving front as the normal to the line or lines fit to the calving front.

The glacier calving fronts are commonly more retreated in the center than at the margins, resulting in a calving front that is concave downglacier. After a series of trials, we found that fitting a maximum of two lines to the calving front provided the best compromise between completeness and simplicity in characterizing the orientation of the fronts, while also characterizing the front geometry on a length scale likely to be similar to that of the glacial earthquakes. In cases where two lines were used, the point separating those two lines was first automatically determined as the most retreated point along the calving front. This selection was then reviewed, and shifted slightly by hand in some cases (for example, if a small 'bite' out of the calving front not generally representative of the overall shape of the front was initially selected). This separation point is not fixed between images, but varies in cross-flow position as the shape of the glacier changes, as seen in Figures 4c, e. We therefore most often report two angles for each image of the calving front, one for the northern or western section of the front, and one for the southern or eastern section. In a smaller number of cases, the calving front was better characterized by a single line or we obtained two orientations that were very similar, differing by $<10^{\circ}$. In those cases, we use a single line and report a single value for the calving-front orientation. 




Fig. 5. Calving-front geometry of the four glaciers discussed in this study: Kangerdlugssuaq Glacier (KGL), Helheim Glacier (HH), Kong Oscar Glacier (KOG), and Jakobshavn Isbræ (JKI). Digitized calving fronts are coloured according to the four epochs described in the text (19992001, 2002-04, 2005-07, and 2008-10). Background shows Landsat 7 images from 15 August 2005 (KGL), 4 August 2005 (HH), 12 August 2005 (KOG), and 9 August 2007 (JKI).

The calving front at Jakobshavn Isbræ is wider and more complicated than that of the other glaciers discussed in this study, particularly following the retreat of the calving front inland of its rock-bounded fjord. There are currently two clearly identifiable regions of high-velocity ice flow at Jakobshavn, terminating at distinct calving fronts (Joughin and others, 2008b). This makes it possible to identify two separate regions of probable high calving flux. Beginning in 2005, we treat Jakobshavn as having two distinct calving fronts, and estimate the orientations of each front separately.

\subsection{Calving-front position}

We also use the digitized calving fronts to estimate calvingfront position over time. To simplify the analysis, we estimate a single, representative position for each measured calving front, calculated as the mean position of all points in the central $3 \mathrm{~km}$ of the calving front. We then project that mean onto the geographic center line and record the projected point as the position of the calving front. The difference in the calculated and projected points is always less than a few 10 s of meters in the along-flow direction.

After determining the position of each measured calving front, we compute annual and multi-annual mean positions. The annual mean is calculated as a simple arithmetic mean. To calculate the multi-annual mean, we weight the annual mean positions by the number of glacial earthquakes occurring in each year for direct comparison with the mean earthquake locations. We use the same four non-overlapping time periods as for the glacial-earthquake locations (1999-2001, 2002-04, 2005-07, and 2008-10). Examples of mean calving-front positions are shown for Helheim Glacier in the lower panel of Figure 3. We express the calving-front positions as relative distances along the geographic center line, as for the earthquake locations, and define the 19992001 mean calving-front position as $0 \mathrm{~km}$. Calving-front retreat leads to positive positions and advance to negative positions, following the sign convention adopted earlier.

\section{RESULTS AND DISCUSSION}

We obtained observations of calving-front orientation and position from more than 250 images of both Helheim Glacier and Kangerdlugssuaq Glacier, 100 images of Kong Oscar Glacier, and 70 images of Jakobshavn Isbræ during the time period 1999-2010. The results of our calving-front orientation measurements are plotted in Figure 6 together with the glacial-earthquake force azimuths. Our position measurements are plotted in Figure 7 with the mean earthquake locations.

\subsection{Calving-front orientation}

\subsubsection{Kangerdlugssuaq Glacier}

At Kangerdlugssuaq Glacier (upper-left panel of Fig. 6), we observe calving-front orientations (reported as the azimuth of the normal to our fit line segments) between $60^{\circ}$ and $180^{\circ}$, with most of the measurements in the range $80-180^{\circ}$. 


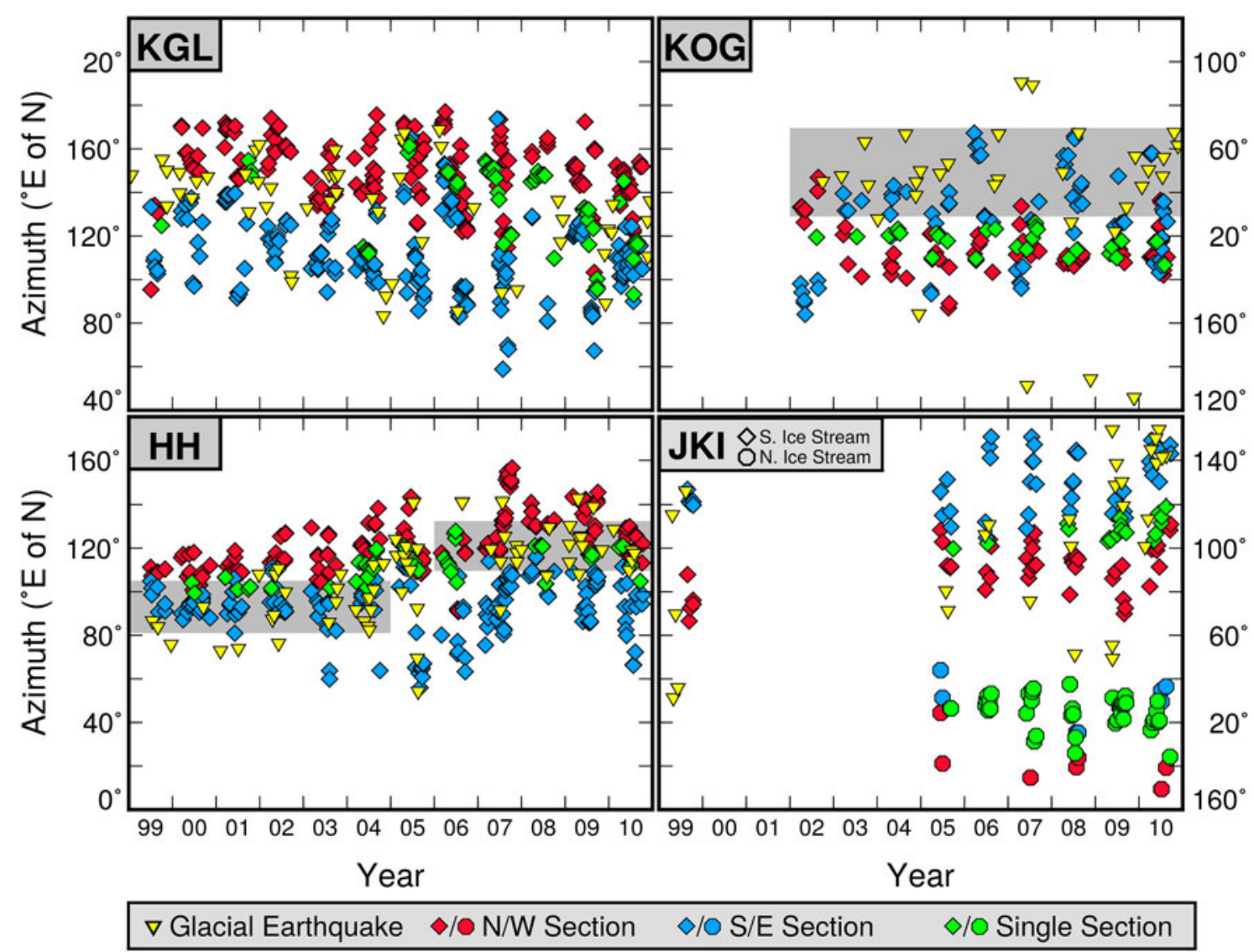

Fig. 6. Comparison of glacial-earthquake force azimuths and measured calving-front orientations for four glaciers: Kangerdlugssuaq Glacier (KGL), Helheim Glacier (HH), Kong Oscar Glacier (KOG) and Jakobshavn Isbræ (JKI). The calving-front orientation is given as the azimuth east of north of the normal to the calving front, as discussed in the 'Data and Methods' section. Gray shading (HH, KOG) shows the range of earthquake force azimuths spanning one std dev. about the mean.

The annual absolute range is consistently $\sim 100^{\circ}$, with little variation from year to year. The mean $\left(132^{\circ}\right)$ and onestandard-deviation range $\left( \pm 23^{\circ}\right)$ of force orientations from the earthquake data and the mean $\left(131^{\circ}\right)$ and one-standarddeviation range $\left( \pm 24^{\circ}\right)$ of calving-front orientations are similar throughout the study period.

This consistency in earthquake force orientations and calving-front orientations includes a period of rapid retreat, much of which occurred during the winter of 2004/05 (Luckman and others, 2006; Howat and others, 2007; Joughin and others, 2008a). As Kangerdlugssuaq retreats, the fjord widens and the calving front grows to include ice from an embayment on the northern side of the glacier (Fig. 4f, 'stagnant ice'), increasing the length and range of potential orientations of the calving front and earthquake force orientations. Any glacial earthquakes from the portion of the calving front contained within the northern embayment would be expected to produce force orientations of $\sim 20^{\circ}$. We interpret the lack of glacial earthquakes with that force orientation to mean that this section of the calving front does not produce glacial earthquakes. Our review of many satellite images suggests that the ice in the embayment is stagnant, and the position and orientation of this portion of the Kangerdlugssuaq calving front barely change over many months.

Retreat of the glacier also exposes two small former tributary glaciers to the ocean on the southern side of the fjord, potentially altering the flow field of the main glacier and creating a new, independent source of calving events. Based on visual inspection of the two newly exposed glaciers, we estimate calving-front orientations of $\sim 20^{\circ}$. However, no earthquakes with that orientation are recorded, and we conclude that none of the glacial earthquakes were generated by these glaciers. It is likely that these relatively small glaciers do not produce large enough calving events to generate globally observable glacial earthquakes.

During our study period, the mean earthquake force azimuth changed from $138^{\circ}$, with a one-standard-deviation range of $21^{\circ}$, during the period $1999-2005$ to $122^{\circ}$ with a one-standard-deviation range of $23^{\circ}$ during the period 2006-10. During the earlier period, the force azimuths span the range of observed calving-front values (mean and standard deviation (std dev.) of $133^{\circ}$ and $24^{\circ}$ ). During the later period, the force azimuths are most consistent with calving from the southern and 'single' sections of the calving front (mean and std dev. of $118^{\circ}$ and $23^{\circ}$ ). This change primarily reflects an overall change in the geometry of the calving front after the $\sim 5 \mathrm{~km}$ retreat that occurred between 2004 and 2005 (Joughin and others, 2008a). The transition in force azimuths is spread over several years (2004-06), suggesting the possible influence of factors other than front position on the calving-front geometry.

Overall, our analysis indicates that variations in the geometry of the central portion of the Kangerdlugssuaq calving front are sufficient to explain the range of observed glacialearthquake force orientations throughout the study period. The combined earthquake and calving-front orientation data indicate that all major calving events from grounded or nearly grounded ice at Kangerdlugssuaq appear to occur in the central portion of the calving front. 


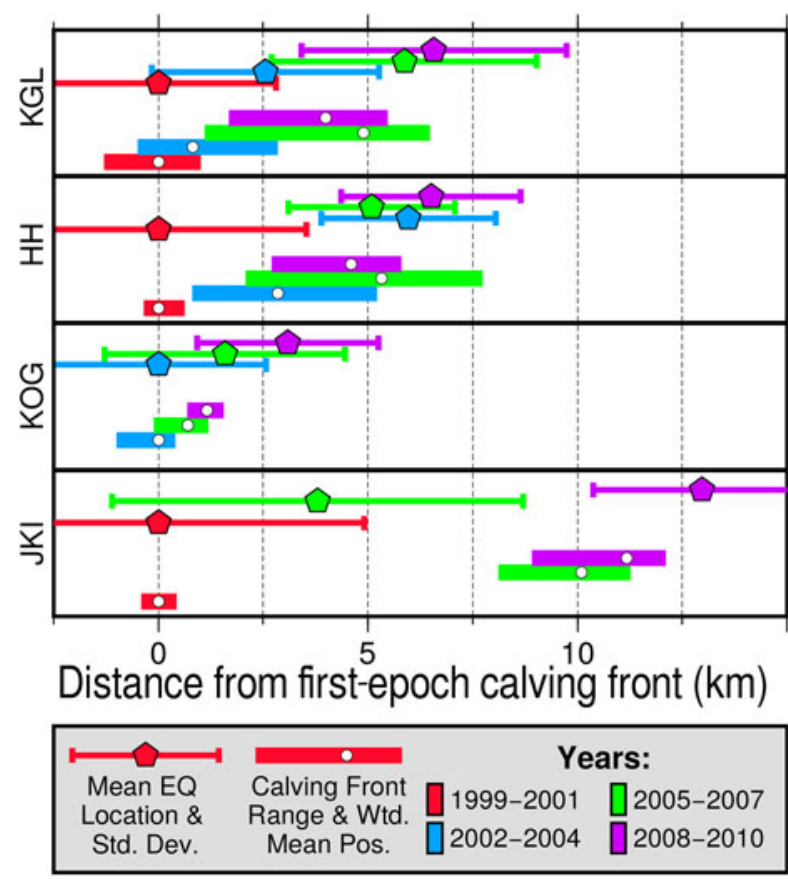

Fig. 7. Comparison of changes in mean earthquake location and weighted-mean calving-front position at Helheim Glacier $(\mathrm{HH})$, Kangerdlugssuaq Glacier (KGL), Kong Oscar Glacier (KOG), and Jakobshavn Isbræ $(\mathrm{JKI})$. Positions are relative, with the origin $(0 \mathrm{~km})$ corresponding to the mean position we obtain for the first time period measured at each glacier, for both the earthquake and calving-front observations. Mean earthquake locations have been projected onto the glacier center line.

\subsubsection{Helheim Glacier}

At Helheim Glacier (lower-left panel of Fig. 6), the measured calving-front orientations range from $60^{\circ}$ to $160^{\circ}$, with most measurements falling between $80^{\circ}$ and $140^{\circ}$. During most years, the measured calving-front orientations show annual absolute ranges of only $40-50^{\circ}$. The range is larger, reaching as much as $90^{\circ}$, during several years in the 2000s, most notably in 2005 when the glacier experienced a large, rapid retreat (Howat and others, 2005; Joughin and others, 2008a).

The mean calving-front orientation $\left(108^{\circ}\right)$ and std dev. $\left(19^{\circ}\right)$ agree well with the mean $\left(107^{\circ}\right)$ and std dev. $\left(19^{\circ}\right)$ observed for the earthquakes. However, both the earthquake force orientations and the calving-front orientations vary with time. The observed force azimuths increase from 1999 to 2005 , and level off after 2005. Most (21 of 27 , or $78 \%$ ) of the force orientations prior to 2005 are less than the 19992010 average orientation of $107^{\circ}$, while nearly all (28 of 29 , or $97 \%$ ) of the force orientations after 2005 have azimuths larger than $107^{\circ}$. The year 2005 shows an atypically large range of force orientations. The mean force orientation during $1999-2005$ is $93^{\circ}\left( \pm 12^{\circ}\right)$, increasing to $121^{\circ}\left( \pm 11^{\circ}\right)$ during 2006-10.

The change in calving-front orientations is less dramatic than the change in the force orientations. Prior to 2005, the mean calving front orientation is $105^{\circ}\left( \pm 13^{\circ}\right)$, increasing to $112^{\circ}\left( \pm 20^{\circ}\right)$ during 2006-10. We believe this difference reflects additional changes in glacier dynamics. Prior to 2005 , the mean angle of the southern section of the calving front $\left(94^{\circ}\right)$ closely matches that of the mean earthquake force orientation over the same period $\left(93^{\circ}\right)$. After 2005, the mean earthquake force orientation $\left(121^{\circ}\right)$ is similar to the mean angle of the northern section of the calving front over this time period $\left(128^{\circ}\right)$. The one-std-dev. range of the force and calving-front orientations remain similar, at $11^{\circ}$ and $14^{\circ}$, respectively. Our data therefore suggest that the primary source of seismogenic calving events shifted from the southern to the northern section of the glacier during 2005.

Several important dynamic changes occurred at Helheim in 2005. Between 2000 and 2005, Helheim retreated nearly $10 \mathrm{~km}$ and accelerated rapidly, from $\sim 6$ to $\sim 11 \mathrm{~km} \mathrm{a}^{-1}$ (Howat and others, 2005; Luckman and others, 2006; Stearns and Hamilton, 2007; Joughin and others, 2008a), while the number of glacial earthquakes occurring annually nearly doubled (Tsai and Ekström, 2007). During summer 2005, Helheim retreated $\sim 2.5 \mathrm{~km}$, past a bedrock low (Joughin and others, 2008a). However, in 2006, the calving front readvanced, attaining a summer position $\sim 3 \mathrm{~km}$ seaward of the 2005 summer position (Joughin and others, 2008a), but still remaining $\sim 4 \mathrm{~km}$ inland of the 1999-2002 position (Bevan and others, 2012). The glacier showed a dramatic reduction in the number of glacial earthquakes, with only one earthquake in 2006 compared with 12 in 2005 (Tsai and Ekström, 2007; Veitch and Nettles, 2012). The number of earthquakes increased again beginning in 2007 (Veitch and Nettles, 2012), after regrounding of the glacier front (Joughin and others, 2008a). Between 2001 and 2006, the lower regions of the glacier also thinned by $\sim 150 \mathrm{~m}$ (Joughin and others, 2008a). Variations in the cross-flow grounding state of the terminus were observed by Murray and others (2015b) during the summer of 2013. Murray and others (2015b) observed that south of a medial moraine the glacier was securely grounded, while north of this moraine several hundred meters of ice behind the terminus was ungrounded. The southern side of the calving margin appears thinner than the northern side, and we speculate that, following 2005, the southern portion of the terminus may have been too thin to produce glacial earthquakes large enough for global detection, either because the ice blocks discharged were too small, or the calving style changed. The observation of differing states north and south of the medial moraine supports the idea that dynamic differences may exist between two regions of the same calving front; such a difference may have led to the preferential occurrence of glacial earthquakes from the northern section of the Helheim terminus following 2005.

\subsubsection{Kong Oscar Glacier}

At Kong Oscar Glacier (upper-right panel of Fig. 6), we observe orientations ranging from $160^{\circ}$ to $180^{\circ}$ and $0^{\circ}$ to $70^{\circ}$ (all calving-front orientations are reported as positive angles for consistency with the earthquake force values), with an annual absolute range of $\sim 60^{\circ}$. The range of observed values remains stable over the study period, though the terminus occasionally switches from a concavedownglacier to convex-downglacier shape, leading to two populations $\left(\sim 40^{\circ}\right.$ and $\left.\sim 180^{\circ}\right)$ of values for the eastern section of the calving front.

Kong Oscar is the second-largest producer of glacial earthquakes in Western Greenland (following Jakobshavn Isbræ), but did not begin producing earthquakes until 2002 (Tsai and Ekström, 2007; Veitch and Nettles, 2012). The calving front at Kong Oscar Glacier appears to have been retreating for at least two decades, though published estimates for the rate of retreat prior to 2002 are variable (Moon and Joughin, 2008; Bevan and others, 2012). Prior to 2002, the terminus 
lacked a distinct front, making it difficult to measure the extent of the glacier precisely (Bevan and others, 2012). Between 2002 and 2010, the glacier retreated $\sim 3 \mathrm{~km}$ (Moon and Joughin, 2008; Bevan and others, 2012), with the majority of the retreat occurring between 2002 and 2006. Between 2002 and 2010, Kong Oscar thinned by 15 m (McFadden and others, 2011) and maintained a steady flow speed (Joughin and others, 2010; Bevan and others, 2012).

The mean calving-front orientation is $21^{\circ}$ with a one-std dev. range of $17^{\circ}$. Glacial earthquakes at Kong Oscar have a mean of $57^{\circ}$ with a std dev. of $31^{\circ}$. Three earthquakes at this glacier are outliers, with force azimuths nearly perpendicular to those of the main population (events with values near $130^{\circ}$ in Fig. 6). When these events are excluded, the mean force azimuth is $49^{\circ}\left( \pm 20^{\circ}\right)$. Agreement in the mean calving-front and force orientations at Kong Oscar is poorer than elsewhere, primarily because most earthquakes appear to have been generated by calving from the eastern section of the glacier margin. In Figure 6, we highlight the one-std dev. range of force azimuths (excluding outliers) to illustrate the consistency of these values with the orientations estimated for the eastern calving front. The mean orientation of the easten section is $29^{\circ}$, a value that is reduced by the population of orientations near $180^{\circ}\left(0^{\circ}\right)$. The values of eastern-front orientations in the range $160-180^{\circ}$ occur in the convex-downglacier configuration, when the glacier terminus is likely to be floating. If we exclude this population of values, the mean orientation becomes $35^{\circ}$, in better agreement with the earthquake values.

Two groups of earthquakes at Kong Oscar Glacier have force orientations that are not well explained by the calving-front orientations we measure either for the eastern or western section of the front. The first group comprises two events with force orientations of $\sim 90^{\circ}$ that occurred in 2007. The second group comprises the three outlier events with force orientations of $\sim 130^{\circ}$, with one event occurring each year from 2007 to 2009 . These five events were also identified as outliers by Veitch and Nettles (2012), who noted that the quality of fit of the observed waveforms to synthetic waveforms for the event source parameters was acceptable and that the event sizes and locations were typical of events at Kong Oscar Glacier.

The first group of events, with force orientations of $\sim 90^{\circ}$, is less problematic. Although these force orientations lie outside the range of calving-front orientations observed in 2007 , they are only $\sim 20^{\circ}$ from calving-front orientations observed in 2006 and 2008 for the eastern portion of the calving front. SLC errors pose a larger problem at Kong Oscar than at any of the other glaciers we consider and, in 2007, SLC errors prevented measurement of the eastern portion of the front. It is possible that the calving front achieved an angle of $\sim 75^{\circ}$ in 2007, as it did in 2006 and 2008 , but that we were unable to observe these orientations in the available imagery. We expect that the disagreement in this case is likely due to a combination of unobserved variation in the calving front and errors in earthquake source-parameter estimates.

For the second group of events, with orientations of $\sim 130^{\circ}$, an explanation relying on missing imagery cannot be reasonably invoked. These three events have force orientations approximately perpendicular to the mean orientation of the calving front, and lie more than $60^{\circ}$ from any observed calving-front orientation in the years prior to or following their occurrence. The only feature associated with Kong
Oscar Glacier that shows an orientation similar to these force orientations is a small, secondary terminus on the south-east side of Kong Oscar Glacier, which meets a bay to the east $\sim 2 \mathrm{~km}$ from the main calving front. This secondary terminus flows slowly and is disconnected from the main flow field (Ahn and Howat, 2011). It is unlikely to be the source of any glacial earthquakes. Possible explanations for the discrepancy we observe are that calving occurred in a direction not parallel to the flow field, or that the source parameters for these events are incorrect. While the CSF inversion scheme applied by Tsai and Ekström (2007) and Veitch and Nettles (2012) appears to be robust in the vast majority of cases, it is possible that some combinations of factors has resulted in erroneous force orientations for these three events at Kong Oscar Glacier. In particular, if these earthquakes are complex or involve multiple subsequent calving events, the simple CSF representation used by Tsai and Ekström (2007) and Veitch and Nettles (2012) may be inadequate for capturing the earthquake source parameters accurately. Both possibilities should be explored further in future studies.

\subsubsection{Jakobshavn Isbræ}

Jakobshavn Isbræ (bottom-right panel of Fig. 6) has a complicated calving-front geometry, with two highly active regions of calving. We measure these two fronts separately from 2005 onwards, and represent them with different symbols in Figure 6. The two regions show calving-front orientations that span nearly the full $180^{\circ}$ of possible orientations but fall into two distinct ranges. The group containing orientations between $60^{\circ}$ and $160^{\circ}$, with a mean of $112^{\circ}$ and a one-standard-deviation range of $20^{\circ}$, represents the calving front associated with the southern ice stream. The group containing orientations predominantly between $0^{\circ}$ and $40^{\circ}$, with a mean of $22^{\circ}$ and one-standard-deviation range of $12^{\circ}$, represents the calving front associated with the northern ice stream. Neither calving front shows a clear trend or change in range of orientation during the study period.

The history of glacial-earthquake occurrence at Jakobshavn, and its relation to evolution of the calving front, was discussed in detail by Veitch and Nettles (2012). In the late 1990s, when Jakobshavn first produced glacial earthquakes, the calving front consisted of a single, wide terminus contained within a rock-bounded fjord, similar to the morphology of the other glaciers discussed here. After 1999 the glacier retreated beyond a pinning point and ceased to produce glacial earthquakes until 2005 (Veitch and Nettles, 2012). In the time period between 1999 and 2005 the glacier retreated beyond the confines of the fjord walls and the terminus geometry evolved so that calving now occurs primarily at two regions of fast flow separated from the rest of the terminus by shear margins. The mean glacial-earthquake force orientation at Jakobshavn is $112^{\circ}$, in good agreement with the mean calving-front orientation for the southern calving front $\left(112^{\circ}\right)$. The one-std-dev. range of force azimuths is $34^{\circ}$, larger than the std dev. $\left(20^{\circ}\right)$ for the calving front, mostly due to earthquakes with azimuths between $40^{\circ}$ and $60^{\circ}$, discussed further below.

Only a few images are available from 1999, the time period during which Jakobshavn was defined by a single, wide calving front. The orientations we measure from those images are generally consistent with the force orientations of glacial earthquakes occurring during that period. Two earthquakes in 
1999 show azimuths $\sim 30^{\circ}$ different from the measured calving fronts, but occurred more than a month before Landsat 7 imagery became available. We believe the shape of the calving front is likely to have changed during this time.

When Jakobshavn began producing glacial earthquakes again in 2005, the glacier had developed a complex terminus shape. Most of the earthquake force orientations observed during this period fall within the range of calving-front orientations measured on the southern terminus region of the glacier (diamond-shaped symbols in Fig. 6). No force orientations fall within the range of measured orientations for the northern terminus region (hexagons, Fig. 6), suggesting that no glacial earthquakes occured at the northern terminus. This interpretation is consistent with our qualitative assessment of the northern calving front: the northern region exhibits slower changes in position than does the southern section and it often lacks the sharp, clearly defined calving front that is present at other glacial-earthquake producing glaciers.

Three earthquakes recorded in 2008 and 2009 have azimuths that fall between the northern and southern calvingfront orientations. We believe there are two possible explanations for these events. First, detailed observations of large calving events at Jakobshavn Isbræ (Amundson and others, 2008; Walter and others, 2012; Sergeant and others, 2016) suggest that some calving events are complex, multi-phase events that involve the capsize of multiple icebergs along large sections of the calving front. The analysis of glacial earthquakes performed by Tsai and Ekström (2007) and Veitch and Nettles (2012) assumes a single earthquake source with one force direction for each event. For a source comprising multiple capsizing icebergs, the earthquake source parameters may have larger errors than they otherwise would.

Second, as the Jakobshavn terminus has continued to retreat, its shape has changed. The Jakobshavn calving front is now bounded by ice margins rather than rock walls, resulting in an increased area of ice exposed to the ocean as a potential source of calving. In some cases, two line segments are insufficient to characterize fully the orientation of the southern calving front, though they capture the orientation of its central, most active portion. It is possible that the earthquakes in question occurred outside of the central section of the southern calving front. We believe it is most likely that the three events occurred at the southern terminus, but occurred on sections of the calving front not fully characterized by our analysis.

\subsection{Position}

In Figure 7, we plot the weighted-mean calving-front position for each time period examined at each glacier as well as the range of positions measured over that time period. The multiannual mean position of the glacial earthquakes is also shown, together with the standard deviations for those mean positions. For Helheim Glacier, Kangerdlugssuaq Glacier and Jakobshavn Isbræ we define the origin as the weighted-mean position for 1999-2001, and for Kong Oscar Glacier as the weighted-mean position for 2002-04.

At Helheim Glacier, the mean position of the calving front retreated $\sim 5 \mathrm{~km}$ between the 1999-2001 and 2005-07 time periods, and remained at approximately the same position in 2008-10. The earthquake locations moved upglacier by slightly more than $5 \mathrm{~km}$ in the 2002-04 time period and remained at approximately the same position during 200507 and 2008-10.
At Kangerdlugssuaq Glacier, the mean calving-front position retreated by $\sim 1 \mathrm{~km}$ between 1999-2001 and 2002-04, and retreated a total of $\sim 5 \mathrm{~km}$ between 1999-2001 and 2005-07, after which time the mean position readvanced by $\sim 1 \mathrm{~km}$. Between 1999-2001 and 2002-04, the mean earthquake position retreated by $\sim 2.5 \mathrm{~km}$, and 2005-07 and 2008-10 show $\sim 6 \mathrm{~km}$ of total retreat compared to 1999-2001.

At Kong Oscar Glacier, the mean calving-front position retreated by $\sim 1 \mathrm{~km}$ between 2002-04 and 2005-07, with a total retreat of slightly less than $2 \mathrm{~km}$ by $2008-10$. The mean earthquake location overestimates this retreat, moving inland by $\sim 2 \mathrm{~km}$ between each time period. However, the one-std-dev. range of the earthquake locations includes the calving-front positions for each time period.

At Jakobshavn Isbræ the mean calving-front position retreated by $\sim 10 \mathrm{~km}$ between 1999-2001 and 2005-07. Much of that retreat, which has been documented in detail by several previous authors, took place during the 2002-04 time period (e.g. Joughin and others, 2004, 2008b). We did not make measurements during 2002-04 because of the lack of glacial earthquakes during that time period. The very small range of positions we observe during 1999-2001 is mainly due to the small number of measurements we attempt from that time period, when few glacial earthquakes occurred. The mean calving-front position retreated another $\sim 2 \mathrm{~km}$ between 2005-07 and 2008-10. The mean earthquake position retreated less than $5 \mathrm{~km}$ between 1999-2001 and 2005-07, but the earthquake positions are highly variable, reflected in the large std dev. The mean earthquake position in 2008-10 retreated $\sim 13 \mathrm{~km}$ from the 1999 to 2001 position.

Clearly, glacial-earthquake source locations should not be used as a primary means of tracking the position of glacier calving fronts; satellite remote-sensing data are vastly superior for such a task. However, large changes in the position of the calving front are reflected in changes in the position of the mean glacial-earthquake locations. In general, the sign and scale of the changes in location of the glacial earthquakes is consistent with the true changes in the positions of the calving fronts. The sensitivity of glacial-earthquake source locations obtained from global seismic data to several-km changes in the location of the calving front underscores the close link between glacial-earthquake source parameters and glacier dynamics. In addition, our results support the practice of using the earthquake locations derived from CSF modeling to identify the source glacier for each earthquake.

\section{CONCLUSIONS}

We have compared estimates of calving-front geometry from satellite imagery with glacial-earthquake source parameters obtained from global seismic analysis using a CSF approach. We find good agreement between earthquake force azimuths and the direction normal to the calving front. Calving-front orientation and glacial-earthquake force orientations remain consistent over time both in cases where a change in orientation is recorded, and where the observed orientations remain stable with time. We conclude that observed variations in glacial-earthquake force azimuth primarily represent true variability in calving-front geometry at the source glacier, rather than errors in the estimates of force azimuth. Despite its simplicity, the CSF source model allows for accurate estimation of calving-front orientation at the time of glacial earthquakes.

We also find that one section of the calving front may be preferred for the production of seismogenic calving events. 
At Kong Oscar Glacier, the eastern portion is preferred during the time period we study. At Helheim Glacier, the preferred region changes over time, apparently in response to changes in glacier dynamics, including changes in glacier thickness and calving-front position.

We identify a small number of cases in which the inferred force orientations differ substantially from observed calvingfront geometries (5 of 180 events analyzed). The simple CSF source model may not be adequate in these cases, and such events warrant further study.

Location estimates for individual glacial earthquakes are accurate enough to allow correct identification of the source glacier. When the earthquake centroid locations are averaged over multiple events to reduce location errors, we find that changes in calving-front location over time explain part of the temporal variability present in glacial-earthquake locations.

Our results demonstrate that temporal variations in glacialearthquake source parameters reflect true variability in the geometry and position of glacier calving fronts. This finding represents an important step toward the use of glacial earthquakes as a tool for remote study of marine-terminating glaciers.

\section{ACKNOWLEDGEMENTS}

The authors appreciate constructive comments from Scientific Editor B. Kulessa, F. Walter, and an anonymous reviewer. This research was supported by National Science Foundation Grants ARC-07-13970 and EAR-09-44055.

\section{REFERENCES}

Ahn Y and Howat I (2011) Efficient automated glacier surface velocity measurement from repeat images using multi-image/ multichip and null exclusion feature tracking. IEEE Trans. Geosci. Remote Sens., 49(8), 2838-2846, ISSN 0196-2892 (doi: 10.1109/TGRS.2011.2114891)

Amundson JM and 5 others (2008) Glacier, fjord, and seismic response to recent large calving events, Jakobshavn Isbræ, Greenland. Geophys. Res. Lett., 35(22), L22501 (doi: 10.1029/ 2008GL035281)

Bevan SL, Luckman AJ and Murray T (2012) Glacier dynamics over the last quarter of a century at Helheim, Kangerdlugssuaq and 14 other major Greenland outlet glaciers. Cryosphere, 6(5), 923937 (doi: 10.5194/tc-6-923-2012)

Chen X, Shearer PM, Walter F and Fricker HA (2011) Seventeen Antarctic seismic events detected by global surface waves and a possible link to calving events from satellite images. J. Geophys. Res., 116(B6), B06311 (doi: 10.1029/2011JB008262)

Ekström G, Nettles M and Abers GA (2003) Glacial earthquakes. Science, 302(5645), 622-624 (doi: 10.1126/science.1088057)

Ekström G, Nettles M and Dziewoński AM (2012) The global CMT project 2004-2010: centroid-moment tensors for 13,017 earthquakes. Phys. Earth Planet. Inter., 200-201, 1-9 (doi: 10.1016/ j.pepi.2012.04.002)

Howat IM, Joughin I, Tulaczyk S and Gogineni S (2005) Rapid retreat and acceleration of Helheim Glacier, east Greenland. Geophys. Res. Lett., 32, L22502 (doi: 10.1029/2005GL024737)

Howat IM, Joughin I and Scambos TA (2007) Rapid changes in ice discharge from Greenland outlet glaciers. Science, 315, 15591561 (doi: 10.1126/science.1138478)

Joughin I, Abdalati W and Fahnestock M (2004) Large fluctuations in speed on Greenland's Jakobshavn Isbræ glacier. Nature, 432, 608-610 (doi: 10.1038/nature03130)
Joughin I and 8 others (2008a) Ice-front variation and tidewater behavior on Helheim and Kangerdlugssuaq Glaciers, Greenland. J. Geophys. Res., 113, F01004 (doi: 10.1029/2007JF000837)

Joughin I and 7 others (2008b) Continued evolution of Jakobshavn Isbrae following its rapid speedup. J. Geophys. Res., 113, F04006 (doi: 10.1029/2008JF001023)

Joughin I, Smith BE, Howat IM, Scambos T and Moon T (2010) Greenland flow variability from ice-sheet-wide velocity mapping. J. Glaciol., 56(197), 415-430 (doi: 10.3189/002214310792447734)

Kawakatsu H (1989) Centroid single force inversion of seismic waves generated by landslides. J. Geophys. Res., 94, 1236312374 (doi: 10.1029/JB094iB09p12363)

Luckman A, Murray T, de Lange R and Hanna E (2006) Rapid and synchronous ice-dynamic changes in East Greenland. Geophys. Res. Lett., 33(3), L03503 (doi: 10.1029/2005GL025428)

McFadden EM, Howat IM, Joughin I, Smith BE and Ahn Y (2011) Changes in the dynamics of marine terminating outlet glaciers in west Greenland (2000-2009). J. Geophys. Res., 116(F2), F02022 (doi: 10.1029/2010JF001757)

Moon T and Joughin I (2008) Changes in ice front position on Greenland's outlet glaciers from 1992 to 2007. J. Geophys. Res., 113, F02022 (doi: 10.1029/2007JF000927)

Murray T and 11 others (2015a) Reverse glacier motion during iceberg calving and the cause of glacial earthquakes. Science, 349(6245), 305-308 (doi: 10.1126/science.aab0460)

Murray T and 9 others (2015b) Dynamics of glacier calving at the ungrounded margin of Helheim Glacier, southeast Greenland. J. Geophys. Res.: Earth Surf., 120(6), 2015JF003531, ISSN 2169-9011 (doi: 10.1002/2015JF003531)

Nettles M and Ekström G (2010) Glacial earthquakes in Greenland and Antarctica. Annu. Rev. Earth Planet. Sci., 38, 467-491 (doi: 10.1146/annurev-earth-040809-152414)

Nettles M and 12 others (2008) Step-wise changes in glacier flow speed coincide with calving and glacial earthquakes at Helheim Glacier, Greenland. Geophys. Res. Lett., 35, L24503 (doi: 10.1029/2008GL036127)

Podrasky D, Truffer M, Lüthi M and Fahnestock M (2014) Quantifying velocity response to ocean tides and calving near the terminus of Jakobshavn Isbrae, Greenland. J. Glaciol., 60 (222), 609-621 (doi: 10.3189/2014JoG13J130)

Sergeant A and 6 others (2016) Complex force history of a calvinggenerated glacial earthquake derived from broadband seismic inversion. Geophys. Res. Lett., 43(3), 1055-1065 (doi: 10.1002/ 2015GL066785)

Smith GP and Ekström G (1997) Interpretation of earthquake epicenter and CMT centroid locations, in terms of rupture length and direction. Phys. Earth Planet. Inter., 102(1-2), 123-132 (doi: 10.1016/S0031-9201(96)03246-3)

Stearns LA and Hamilton GS (2007) Rapid volume loss from two East Greenland outlet glaciers quantified using repeat stereo satellite imagery. Geophys. Res. Lett., 34, L05503 (doi: 10.1029/ 2006GL028982)

Tsai VC and Ekström G (2007) Analysis of glacial earthquakes. J. Geophys. Res., 112, F03S22 (doi: 10.1029/2006JF000596)

Tsai VC, Rice JR and Fahnestock M (2008) Possible mechanisms for glacial earthquakes. J. Geophys. Res., 113, F03014 (doi: 10.1029/ 2007JF000944)

Veitch SA and Nettles M (2012) Spatial and temporal variations in Greenland glacial-earthquake activity, 1993-2010. J. Geophys. Res.: Earth Surf., 117(F4), 1-20 (doi: 10.1029/ 2012JF002412)

Walter $\mathrm{F}$ and 5 others (2012) Analysis of low-frequency seismic signals generated during a multiple-iceberg calving event at Jakobshavn Isbræ, Greenland. J. Geophys. Res., 117, F01036 (doi: 10.1029/2011JF002132) 